\title{
Transforming Conventional Teaching Classroom to Learner-Centred Teaching Classroom Using Multimedia-Mediated Learning Module
}

\author{
Yap Wei Li
}

\begin{abstract}
There are higher education institutions in Malaysia which at the stage of transforming from teacher-centred teaching in the classroom to a more learner-centred teaching environment. The process has been slow due to lack of guidelines provided and teachers are lack of confidence. This research addresses the difficulties or challenges faced by the higher education institutions in such effort and also further investigate the impact of learner-centred teaching. A case study was conducted at INTI International University, Malaysia where it realized the limitations of conventional teaching and had taken initiatives to encourage lecturers to adopt a more learner-centred teaching approach. This research was found to be significant because there are many discussions which focused on various learning activities for student-centred learning but there is lack of focus given on the teachers, what teachers can do in order to achieve student-centred learning, especially for education institutions which are at the beginning stage of moving towards student-centred learning environment. With the assistance of technology, various learning tools or techniques were introduced and incorporated into teaching and learning process. This includes the online learning environment which supports synchronous and asynchronous learning. Besides that, multimedia technology can also be used in designing the learning module as it can gain better attention from students, increase learner motivation and improve retention rate. This research adopted Weimer's Learner-Centred Teaching model which addresses key strategies to help education institutions to achieve such transformation in a more systematic approach by having clear guidelines for teachers. This study compared the conventional teaching with the multimedia learning and also the online learning in terms of their implications on learner understanding and learner motivation through the use of pre-test/ post-test, surveys and students' comments.
\end{abstract}

Index Terms-Learner-centred teaching, multimedia learning, online learning, technology in education.

\section{INTRODUCTION}

The conduct of education in this $21^{\text {st }}$ century has been witnessed with a paradigm shift from face-to-face teaching environment to a more technology-based learning environment. The advancement of ICT has influenced the development of education [1]. For example, interactive multimedia learning applications were introduced to the classrooms, blended learning and distance learning which involve web-based learning were implemented. With these new applications and learning platform, students are exposed

Manuscript received August 9, 2014; revised Ocotober 10, 2014.

Yap Wei Li is with the INTI International University, Malaysia (e-mail: desiree.yap@newinti.edu.my). to a more student-centred learning experience. Reference [2] posited "the use of computer-based technology in college education has dramatically increased to include emerging technology for visual presentation, simulation, accessing course materials and World Wide Web resources, and interactivity".

The use of technology in education is necessary because students are known as digital natives. Students nowadays are highly connected with technology in their daily lives. They use Internet to search for information to assist their learning. They also experience various ways of collaboration and communication with their peers and teachers through social networking tools and also chatting software. It has been a norm to see how frequent students use technology in their learning. Therefore, it is necessary to use technology in education to enhance students' learning experiences. Although technology can be positively influenced learning, there are teachers who do not have confidence to include them in their teaching. Due to lack of guidelines provided to teachers and education institutions on how they can transform from conventional teaching to learner-centred teaching, many times technology is used for the sake of using it.

Using multimedia in learning can also help to promote deeper learning and has positive impact in creating a learner-centred teaching environment. Multimedia learning is able to gain better attention from learners, achieve higher retention rate and also encourage better participation rate among learners [3]-[5]. Multimedia learning is said to be effective in the transformation process from traditional teaching approach to blended learning and also to online learning [6]-[8]. Having the technology in education and also the use of multimedia learning, this would help bridge the transition gap of moving towards learner-centred teaching [9].

This study further investigates the processes which can provide more insights to the teachers on what they can prepare and do in order to move towards learner-centred teaching in a more progressive manner. This study intends to report effect of each learning environment on learner understanding and also students' perception on the learning environments through three instruments, which are pretest/ posttest, survey questionnaire and students' comments.

\section{BACKGROUND STUDY}

\section{A. Limitations of Conventional Teaching}

Conventional teaching or traditional teaching refers to a teaching method involving instructors and the students 
interacting in a face-to-face manner in the classroom. These instructors initiate discussions in the classroom, and focus exclusively on knowing content in textbooks and notes. Students receive the information passively and reiterate the information memorized in the exams [10]. Technology in education is not something new in today's classrooms, but many education systems are still limited by conventional teaching and learning methods [11]. Many teachers are still teaching their students in the same manner as how they were taught and how their own teachers were taught, not much of progress in terms of the teaching perspectives [12]. Transformation to less conventional methods of teaching results is in fear and reluctance from teachers, who find the change hard and risky [13]. Reference [14] noted that many lecturers are still using conventional teaching and have noted that in conventional teaching classrooms, while the lecturer is explaining and writing on the board, students will be copying the same thing onto their notes, some day-dreaming and some sleeping. It would be difficult to stop students from copying the notes from the board and at the same time ensured that every student was paying attention in the class because the lecturer was too busy explaining the lecture. Conventional teaching is also limiting the room for more creative thinking and also seldom considering individual differences. It is necessary to realize these limitations in conventional teaching and take a step to move forward.

\section{B. Technology in Education}

Information and Communication Technology is playing an active role now in education where it can promote learning through the interactivity feature exists in it. Technology serves as the mediator to form interactive learning with students' participation [15]. In Malaysia, Ministry of Education had implemented the project of "smart school" with the name of "Malaysian Smart School Flagship" since 1999. In this initiative, it is believed that the teaching and learning process can be reinvented and the students are well prepared in this current information age. The traditional classroom teaching is transformed into different setting where Information and Communication Technology (ICT) and multimedia technologies are involved in the process. The role of teacher is changed from purely providing information to a facilitator where students are encouraged to explore for more information and justify the correctness of the information (Multimedia Super Corridor Malaysia [MSC Malaysia], 2006-2007). Another reason for having such project in Malaysia because students are growing up in the world of technology, using the Internet to search for information is not strange to them anymore. Students like to see lecturers to develop the teaching materials in presentation software such as Microsoft PowerPoint where the multimedia elements (graphics, animation, sound, video and text) can be used to attract the students' attention [2]. The use of technology in the classroom has not increased much on the learner-centred practices. It is also noted that when tradition education involves technology, it does not mean education reformation will take place automatically. It is important for education institutions to understand students' learning needs and not focusing to have technology alone. Therefore, technology is to be treated as part of the learning process but not the process itself.

\section{Learner-Centred Teaching}

Besides the understanding the new paradigm of education in this $21^{\text {st }}$ century can bring great impact to the students, it is greatly important to also understand the new roles which can be played by teachers and students in the classroom. In order to improve students' learning process, [9] proposed to the faculty and educators to consider five key changes to be taken place which can promote learner-centred teaching at the same time. Learner-centred teaching encourages lecturers to put students learning in the center. Educators can consider incorporating five key changes into their instructional practices [9].

\section{1) The role of the teacher}

Instead of having the teacher covering the syllabus from a-z in the classroom, the teachers shall encourage students to become active learners where their role changes from "teacher" to "facilitator".

\section{2) The balance of power}

In learner-centred teaching, teachers start to share the decision making with the students. In such situation, students are involved more in the learning process rather than having teachers to decide everything for the students.

\section{3) The function of content}

The content used in the classroom delivery shall be able to promote critical thinking skill, problem solving skill and to develop their learning skill and increase self-learning awareness besides the ordinary function which is deliver the knowledge to students.

\section{4) The responsibility for learning}

In learner-centred teaching environment, students are encouraged to play the active role in learning where they will be aware of their learning responsibility. Students do not feel being "forced" to look at the study materials and in fact they will be motivated to be more independent and have controls on how they want to study. As such, students will need lecturers lesser since they will have the responsibility for learning.

\section{5) The process and purpose of evaluation}

The evaluation adopted in the courseworks shall be able to promote learning and help students to develop their learning skills. Learner-centred teaching promotes the use of self-assessment or peer assessment because this can avoid the courses to be grade-oriented and evaluated by teachers only.

\section{Online Learning}

There are various ways for students to explore more information. It is common nowadays Internet is used widely in education. Learning is facilitated conveniently in web-based environment. One common tool students like to use is Internet, and followed by another form which is e-learning [16]. The students find learning using the technology is helpful to their study as well besides the conventional teaching environment because this new way of learning is not boring, they still can interact with the computer or the learning application. Therefore, it is also considered as interactive learning.

Why are educational institutions moving to online learning 
environment? Firstly, the education sector has recognized the importance of involving web-based learning due to the fact that the students nowadays are belong to the "digital age", it creates the sense of familiarization for them. Hence, the students' interest for learning is stimulated. Secondly, this learning environment is able to provide synchronous and asynchronous learning activities with the exchange of knowledge on the data communication platform where the students are allowed to communicate with the learning materials and also educators. This provides the opportunity for the students to learn through an interesting manner with the inclusion of interactivity provided in the context. Thirdly, online learning environment is popular because it has the effect on enhancing learners' engagement which influences the results of learners' achievement, learners' retention and personal development. Lastly, this learning environment is also contributing to the effectiveness of facilitation [5].

\section{E. Multimedia Learning}

It is common to see universities use instructional multimedia in course delivery as this is considered as part of the educational technology. It is not strange anymore to involve lecturers and students using multimedia technology in the classrooms. This is due to many benefits of multimedia technology can bring into the classroom. Reference [17] posited that "Advantages of instructional multimedia include increased availability and repetition of instructional content, improved ability of students to learn at their own pace, increased student control of material, less demand on instructor time, and the provision of an alternative approach to describe complex topics or three-dimensional relationships". The involvement of multimedia in education is getting important as it is able to improve the students' learning outcome.

Multimedia technology can attract students' attention easily. Once students are attracted to the multimedia presentation, they are motivated in a way to continue exploring the presentation. When this process goes on, the students are engaged in the learning process. Hence, the multimedia technology is able to create some initiatives for the students to keep learning. In University of Texas at Austin, USA, three teachers had conducted a study which is on using multimedia enhanced problem-based learning environment to teach Science. The study has shown that this learning environment is not boring and students are motivated to learn Science [18].

\section{Methodology}

This study was conducted at INTI International University in Malaysia. The participants of this study were Business students from Diploma in Business Administration (DBAD). There were a total of 68 students local and international students involved in this study. It was their first semester they took their first IT subject.

There were three different learning environments in this study, first was the face-to-face teaching using PowerPoint, second was the blended learning using multimedia learning module and the third was the web learning using multimedia learning module. The students were given a set of 20 multiple questions (pre-test) a week before the conduct of the lecture for each learning environment. Once they had their lecture, they did the same set of questions (post-test) again. In the next class, students were given the questionnaire in order to gather students' perceptions on the learning environment which they went through.

\section{ANALYSIS AND DISCUSSION}

\section{A. Student Learning Outcome}

During the conduct of the study, the number of students involved is listed below:

- Face-to-face teaching $(\mathrm{F} 2 \mathrm{~F})=14$

- Learning with multimedia $(\mathrm{MM})=24$

- Web learning with multimedia (Web) $=30$

The following table shows mean scores for the Pre-test and Post-test conducted in the three learning environments. Pre-test and Post-test consists of full marks of 20.

TABLE I: MEAN SCORES FOR PRETEST AND POSTTEST
\begin{tabular}{|l|l|l|l|}
\hline & $\boldsymbol{N}$ & Mean & STD \\
\hline F2F: Pre-test & 14 & 7.64 & 2.061 \\
\hline F2F: Post-test & 14 & 11.64 & 2.205 \\
\hline MM: Pre-test & 24 & 8.46 & 2.813 \\
\hline MM: Post-test & 24 & 11.92 & 3.006 \\
\hline Web: Pre-test & 30 & 8.10 & 2.496 \\
\hline Web: Post-test & 30 & 12.80 & 3.253 \\
\hline
\end{tabular}

From Table I above, it indicated that the post-test mean score of the web learning was the highest among all. This shows that the web learning environment was able to contribute in improving students' performances, meaning students had successfully understood the content through accessing this web-based learning module. The score difference of pre-test and post-test results was found to be normally distributed where it achieved .606 in the Shapiro-Wilk test.

The results of the Paired Sample T-Test in all three learning environments are shown below:

TABLE II: PAIRED SAMPLE T-TEST

\begin{tabular}{|c|c|c|c|c|c|c|c|c|}
\hline \multicolumn{9}{|c|}{ Paired Sample Test } \\
\hline & \multicolumn{5}{|c|}{ Paired Differences } & \multirow{3}{*}{ t } & \multirow{3}{*}{ df } & \multirow{3}{*}{$\begin{array}{l}\text { Sig. } \\
\text { (2-tail } \\
\text { ed) }\end{array}$} \\
\hline & \multirow[t]{2}{*}{ Mean } & \multirow{2}{*}{$\begin{array}{l}\text { Std. } \\
\text { Deviatio } \\
\text { n }\end{array}$} & \multirow{2}{*}{$\begin{array}{l}\text { Std. } \\
\text { Error } \\
\text { Mean }\end{array}$} & \multicolumn{2}{|c|}{$\begin{array}{l}95 \% \text { Confidence } \\
\text { Interval of the } \\
\text { Difference }\end{array}$} & & & \\
\hline & & & & Lower & Upper & & & \\
\hline $\begin{array}{l}\text { F2F: } \\
\text { Pre-test - } \\
\text { Post-test }\end{array}$ & -4.000 & 2.075 & .555 & -5.198 & -2.802 & -7.211 & 13 & .000 \\
\hline $\begin{array}{l}\text { MM: } \\
\text { Pre-test - } \\
\text { Post-test }\end{array}$ & -3.458 & 3.538 & .722 & -4.952 & -1.964 & -4.788 & 23 & .000 \\
\hline $\begin{array}{l}\text { Web: } \\
\text { Pre-test - } \\
\text { Post-test }\end{array}$ & -4.700 & 3.303 & .603 & -5.933 & -3.467 & -7.795 & 29 & .000 \\
\hline
\end{tabular}

From the above Paired Sample T-Test results tabulated in Table II, the differences of the pretest and posttest mean 
scores in all three learning environments are significant, it is because the $p$-value is less than .05 [19].

\section{B. Learning Environment Survey Results}

The survey was used to investigate students' perceptions on the learning environment that they went through, whether they were able to achieve better understanding. The survey was measured in 5 points Likert scale ( 1 for Strongly Disagree, 2 for Disagree, 3 for Undecided, 4 for Agree, and 5 for Strongly Agree). It was noted that the learner-centred teaching environment successfully helped students to gain better understanding, makes the learning process more interesting and engaging. There are 20 items asked in the face-to-face teaching with PowerPoint, 30 items asked in the learning with multimedia environment (additional items related to multimedia learning) and 35 items asked in the web learning environment (additional items related to web features). The following Table III - Table V show the mean scores, standard deviation, percentages and Cronbach's Alpha for the perception on the three learning environments:

TABLE III: MEANS AND PERCENTAGES FOR THE PERCEPTION ON FACE-TO-FACE TEACHING WITH POWERPOINT ENVIRONMENT

\begin{tabular}{|c|c|c|c|c|}
\hline No & Survey Items & $\begin{array}{l}\text { Mean } \\
(M)\end{array}$ & STD & $\%$ \\
\hline 1 & $\begin{array}{l}\text { The presence of the lecturer during this } \\
\text { lecture was helpful }\end{array}$ & 4.21 & .802 & 78.6 \\
\hline 2 & $\begin{array}{l}\text { The design of the lecture was suitable for me } \\
\text { to learn the content }\end{array}$ & 4.00 & .555 & 85.7 \\
\hline 3 & $\begin{array}{l}\text { The lecturer helped me understand the } \\
\text { concepts in the lecture better. }\end{array}$ & 3.86 & .663 & 71.4 \\
\hline 4 & $\begin{array}{l}\text { I enjoyed having the lecturer present to } \\
\text { answer any of my questions }\end{array}$ & 3.86 & .663 & 71.4 \\
\hline 5 & $\begin{array}{l}\text { The content was clear and logically } \\
\text { organized }\end{array}$ & 3.79 & .699 & 64.3 \\
\hline 6 & $\begin{array}{l}\text { Important information or key concepts were } \\
\text { easy to identify }\end{array}$ & 3.71 & .914 & 57.1 \\
\hline 7 & $\begin{array}{l}\text { The content presented in the lecture was } \\
\text { relevant to my learning }\end{array}$ & 3.64 & .497 & 64.3 \\
\hline 8 & $\begin{array}{l}\text { I was able to maintain contact with the } \\
\text { lecturer at all times }\end{array}$ & 3.57 & .852 & 50.0 \\
\hline 9 & $\begin{array}{l}\text { Text and graphics made understanding the } \\
\text { content better }\end{array}$ & 3.57 & .646 & 50.0 \\
\hline 10 & I was clear about the objectives of the lecture & 3.57 & .646 & 64.3 \\
\hline 11 & The content was easy to understand & 3.50 & .760 & 50.0 \\
\hline 12 & $\begin{array}{l}\text { I found that there was just the right amount of } \\
\text { information on each screen }\end{array}$ & 3.50 & .650 & 42.8 \\
\hline 13 & $\begin{array}{l}\text { I was able to learn better with the } \\
\text { conventional method of teaching }\end{array}$ & 3.50 & .760 & 35.7 \\
\hline 14 & $\begin{array}{l}\text { I know better about the subject after the } \\
\text { lecture }\end{array}$ & 3.50 & .760 & 50.0 \\
\hline 15 & $\begin{array}{l}\text { I enjoyed learning with the conventional } \\
\text { method of teaching }\end{array}$ & 3.50 & .855 & 42.9 \\
\hline 16 & $\begin{array}{l}\text { I understood the course content after the } \\
\text { lecture }\end{array}$ & 3.43 & .756 & 57.1 \\
\hline 17 & I found the lecture interesting and engaging & 3.43 & .852 & 50.0 \\
\hline 18 & I liked the conventional method of teaching. & 3.29 & .914 & 42.8 \\
\hline 19 & $\begin{array}{l}\text { I was interested to learn more about the topic } \\
\text { after the lecture }\end{array}$ & 3.14 & .663 & 28.6 \\
\hline 20 & $\begin{array}{l}\text { I was motivated learning with the } \\
\text { conventional method of teaching }\end{array}$ & 3.07 & 1.072 & 28.6 \\
\hline & Cronbach's Alpha & .833 & & \\
\hline
\end{tabular}

TABLE IV: MEANS AND PERCENTAGES FOR THE PERCEPTION ON LEARNING WITH MULTIMEDIA ENVIRONMENT

\begin{tabular}{|c|c|c|c|c|}
\hline No & Survey Items & $\begin{array}{l}\text { Mean } \\
(M)\end{array}$ & STD & $\%$ \\
\hline 1 & $\begin{array}{l}\text { The presence of the lecturer during this } \\
\text { module was helpful }\end{array}$ & 3.96 & .624 & 79.2 \\
\hline 2 & $\begin{array}{l}\text { The lecturer helped me understand the } \\
\text { concepts in the module better }\end{array}$ & 3.83 & .702 & 66.7 \\
\hline 3 & $\begin{array}{l}\text { The content was clear and logically } \\
\text { organized }\end{array}$ & 3.83 & .637 & 70.8 \\
\hline 4 & $\begin{array}{l}\text { The design of the multimedia learning } \\
\text { module was suitable for me to learn the } \\
\text { content }\end{array}$ & 3.83 & .637 & 70.8 \\
\hline 5 & I liked the multimedia learning module & 3.79 & .779 & 66.7 \\
\hline 6 & $\begin{array}{l}\text { Multimedia made understanding the content } \\
\text { better }\end{array}$ & 3.79 & .658 & 66.7 \\
\hline 7 & $\begin{array}{l}\text { I enjoyed learning with the multimedia } \\
\text { learning module }\end{array}$ & 3.79 & .833 & 70.9 \\
\hline 8 & $\begin{array}{l}\text { I liked learning with this method than in the } \\
\text { traditional classroom }\end{array}$ & 3.75 & .676 & 62.5 \\
\hline 9 & $\begin{array}{l}\text { I liked the use of multimedia to illustrate } \\
\text { ideas and concepts }\end{array}$ & 3.75 & .794 & 75.0 \\
\hline 10 & $\begin{array}{l}\text { The buttons and links were easy to } \\
\text { understand }\end{array}$ & 3.75 & .794 & 62.5 \\
\hline 11 & $\begin{array}{l}\text { Multimedia made learning fun and } \\
\text { motivating }\end{array}$ & 3.75 & .676 & 70.8 \\
\hline 12 & $\begin{array}{l}\text { I enjoyed having the lecturer present to } \\
\text { answer any of my questions during the } \\
\text { module presentation }\end{array}$ & 3.71 & .690 & 66.6 \\
\hline 13 & $\begin{array}{l}\text { The content presented in the module was } \\
\text { relevant to my learning }\end{array}$ & 3.71 & .550 & 66.7 \\
\hline 14 & $\begin{array}{l}\text { Important information or key concepts were } \\
\text { easy to identify }\end{array}$ & 3.67 & .761 & 66.6 \\
\hline 15 & $\begin{array}{l}\text { I liked being able to learn with } \\
\text { multimedia-oriented modules }\end{array}$ & 3.54 & .588 & 58.3 \\
\hline 16 & The content was easy to understand & 3.50 & .834 & 58.4 \\
\hline 17 & $\begin{array}{l}\text { The interface of the multimedia learning } \\
\text { module was clearly structured and appealing }\end{array}$ & 3.50 & .659 & 50.0 \\
\hline 18 & I liked the multimedia content in the module & 3.50 & .659 & 50.0 \\
\hline 19 & I was motivated learning with the module & 3.50 & .590 & 54.2 \\
\hline 20 & $\begin{array}{l}\text { I found learning with the module interesting } \\
\text { and engaging }\end{array}$ & 3.50 & .834 & 54.1 \\
\hline 21 & $\begin{array}{l}\text { I was interested to learn more about the topic } \\
\text { after going through the multimedia learning } \\
\text { module }\end{array}$ & 3.50 & .722 & 54.2 \\
\hline 22 & $\begin{array}{l}\text { The interactive features in the module made } \\
\text { learning fun and engaging }\end{array}$ & 3.46 & .721 & 50.0 \\
\hline 23 & $\begin{array}{l}\text { The interactive features in the module } \\
\text { motivated me to learn the content }\end{array}$ & 3.46 & .721 & 41.6 \\
\hline 24 & $\begin{array}{l}\text { I was able to follow the navigation easily in } \\
\text { the module }\end{array}$ & 3.46 & .658 & 45.9 \\
\hline 25 & $\begin{array}{l}\text { I was able to maintain contact with the } \\
\text { lecturer at all times }\end{array}$ & 3.42 & .584 & 45.8 \\
\hline 26 & $\begin{array}{l}\text { I found that there was just the right amount of } \\
\text { information on each screen }\end{array}$ & 3.38 & .647 & 37.5 \\
\hline 27 & $\begin{array}{l}\text { I was able to learn better with multimedia } \\
\text { content }\end{array}$ & 3.33 & .761 & 41.7 \\
\hline 28 & $\begin{array}{l}\text { I knew better about the subject with the } \\
\text { multimedia learning module }\end{array}$ & 3.33 & .761 & 41.7 \\
\hline 29 & $\begin{array}{l}\text { I was clear about the objectives of the } \\
\text { multimedia learning module }\end{array}$ & 3.33 & .761 & 41.7 \\
\hline 30 & $\begin{array}{l}\text { I understood the course content in the } \\
\text { multimedia learning module }\end{array}$ & 3.25 & .737 & 41.7 \\
\hline & Cronbach's Alpha & .878 & & \\
\hline
\end{tabular}


TABLE V: MEANS AND PeRCENTAges For the PERCEPTION ON LEARNing WITH MULTIMEDIA ENVIRONMENT

\begin{tabular}{|c|c|c|c|c|}
\hline No & Survey Items & $\begin{array}{l}\text { Mean } \\
(M)\end{array}$ & STD & $\%$ \\
\hline 1 & $\begin{array}{l}\text { My learning process was better with lecturer's } \\
\text { presence in the class. }\end{array}$ & 4.33 & .653 & 90.0 \\
\hline 2 & I understood the content easily. & 4.07 & .767 & 82.9 \\
\hline 3 & $\begin{array}{l}\text { I could easily find out which points were } \\
\text { important. }\end{array}$ & 4.06 & .832 & 77.1 \\
\hline 4 & $\begin{array}{l}\text { I could understand the graphics in the web-based } \\
\text { multimedia learning module. }\end{array}$ & 4.06 & .814 & 75.7 \\
\hline 5 & $\begin{array}{l}\text { I could understand the instructions in the } \\
\text { web-based multimedia learning module. }\end{array}$ & 4.03 & .589 & 87.1 \\
\hline 6 & I found the content was well organized. & 4.01 & .771 & 77.1 \\
\hline 7 & $\begin{array}{l}\text { I enjoyed being able to control the time spent and } \\
\text { speed in learning. }\end{array}$ & 4.01 & .893 & 75.7 \\
\hline 8 & The navigation links and buttons were all correct. & 4.00 & .851 & 78.6 \\
\hline 9 & $\begin{array}{l}\text { I liked being able to search information on the } \\
\text { web. }\end{array}$ & 4.00 & .816 & 80.0 \\
\hline 10 & I found this learning environment motivating. & 4.00 & .868 & 78.6 \\
\hline 11 & I liked to learn in this learning environment. & 3.99 & .732 & 78.6 \\
\hline 12 & $\begin{array}{l}\text { I liked being able to communicate with my } \\
\text { lecturer and classmates via email or other tools. }\end{array}$ & 3.97 & .798 & 75.7 \\
\hline 13 & I was engaged in this learning environment. & 3.96 & .770 & 78.6 \\
\hline 14 & $\begin{array}{l}\text { The information in the module was based on the } \\
\text { syllabus. }\end{array}$ & 3.96 & .711 & 78.6 \\
\hline 15 & I could find answers in the learning module. & 3.96 & .711 & 75.7 \\
\hline 16 & $\begin{array}{l}\text { I enjoyed learning through the multimedia } \\
\text { contents. }\end{array}$ & 3.96 & .924 & 77.1 \\
\hline 17 & I could achieve all the objectives for this chapter. & 3.96 & .788 & 77.1 \\
\hline 18 & $\begin{array}{l}\text { I understood better through the use of } \\
\text { multimedia. }\end{array}$ & 3.94 & .866 & 72.9 \\
\hline 19 & $\begin{array}{l}\text { I was engaged with the help of interactivity in the } \\
\text { module. }\end{array}$ & 3.93 & .822 & 71.4 \\
\hline 20 & $\begin{array}{l}\text { I agreed that multimedia could explain the } \\
\text { concept easily. }\end{array}$ & 3.93 & .840 & 75.7 \\
\hline 21 & Multimedia content helped me to learn better. & 3.91 & .913 & 67.1 \\
\hline 22 & $\begin{array}{l}\text { I found the overall design of the web-based } \\
\text { module to be attractive. }\end{array}$ & 3.91 & .697 & 74.3 \\
\hline 23 & $\begin{array}{l}\text { Web-based module helped me understood the } \\
\text { chapter. }\end{array}$ & 3.89 & .733 & 72.9 \\
\hline 24 & $\begin{array}{l}\text { I found the overall design being suitable for } \\
\text { learning. }\end{array}$ & 3.89 & .772 & 72.9 \\
\hline 25 & $\begin{array}{l}\text { I had no problem in navigating the web-based } \\
\text { module. }\end{array}$ & 3.87 & .741 & 78.6 \\
\hline 26 & $\begin{array}{l}\text { The amount of information on the screen was just } \\
\text { right. }\end{array}$ & 3.83 & .816 & 65.7 \\
\hline 27 & $\begin{array}{l}\text { I would want to find out more information about } \\
\text { the contents after the lesson. }\end{array}$ & 3.80 & .878 & 68.6 \\
\hline 28 & The interactivity level was enough. & 3.80 & .827 & 64.3 \\
\hline 29 & This learning environment motivated me. & 3.79 & .866 & 72.9 \\
\hline 30 & $\begin{array}{l}\text { I was motivated through the interactivity } \\
\text { provided. }\end{array}$ & 3.77 & .802 & 64.3 \\
\hline 31 & $\begin{array}{l}\text { After this web-based learning, I gained much } \\
\text { knowledge. }\end{array}$ & 3.77 & .820 & 67.1 \\
\hline 32 & The objectives were made clearly to me. & 3.77 & .820 & 67.1 \\
\hline 33 & The loading speed was satisfactorily. & 3.76 & .908 & 58.6 \\
\hline 34 & I would want this learning method in future. & 3.70 & .906 & 62.9 \\
\hline \multirow[t]{2}{*}{35} & $\begin{array}{l}\text { I prefer this learning method than the } \\
\text { conventional approach. }\end{array}$ & 3.67 & 1.003 & 58.6 \\
\hline & Cronbach's Alpha & .945 & & \\
\hline
\end{tabular}

The survey items can be further discussed in the following factors:

\section{Understanding}

TABLE VI: UNDERSTANDING (F2F)

\begin{tabular}{|l|l|l|l|l|}
\hline No & Survey Items & $\begin{array}{l}\text { Mean } \\
(\mathbf{M})\end{array}$ & STD & $\%$ \\
\hline 7 & $\begin{array}{l}\text { The content presented in the lecture was } \\
\text { relevant to my learning }\end{array}$ & 3.64 & .497 & 64.3 \\
\hline 10 & I was clear about the objectives of the lecture & 3.57 & .646 & 64.3 \\
\hline 11 & The content was easy to understand & 3.50 & .760 & 50.0 \\
\hline 14 & $\begin{array}{l}\text { I know better about the subject after the } \\
\text { lecture }\end{array}$ & 3.50 & .760 & 50.0 \\
\hline 13 & $\begin{array}{l}\text { I was able to learn better with the } \\
\text { conventional method of teaching }\end{array}$ & 3.50 & .760 & 35.7 \\
\hline 16 & $\begin{array}{l}\text { I understood the course content after the } \\
\text { lecture }\end{array}$ & 3.43 & .756 & 57.1 \\
\hline
\end{tabular}

Table VI above presents the survey items related to learner understanding. Students in this conventional teaching environment were able to gain understanding after the class being conducted. However, in terms of the degree of understanding, it was not as great as the other two learning environments. Students actually liked to have lecturer's presence in the class and they agreed that lecturer could help them to learn or understand the course content. However, when the role of teacher is an authoritarian, students were not able to be involved actively in the learning process. Therefore, the result of the survey in supporting this "understanding" aspect was lower in this learning environment. The grand mean score was 3.52 .

\begin{tabular}{|c|c|c|c|c|}
\hline No & Survey Items & $\begin{array}{l}\text { Mean } \\
(M)\end{array}$ & STD & $\%$ \\
\hline 6 & $\begin{array}{l}\text { Multimedia made understanding the content } \\
\text { better }\end{array}$ & 3.79 & .658 & 66.7 \\
\hline 18 & $\begin{array}{l}\text { The content presented in the module was } \\
\text { relevant to my learning }\end{array}$ & 3.71 & .550 & 66.7 \\
\hline 30 & $\begin{array}{l}\text { I understood the course content in the } \\
\text { multimedia learning module }\end{array}$ & 3.71 & .784 & 61.9 \\
\hline 16 & The content was easy to understand & 3.50 & .834 & 58.4 \\
\hline 27 & $\begin{array}{l}\text { I was able to learn better with multimedia } \\
\text { content }\end{array}$ & 3.33 & .761 & 41.7 \\
\hline 29 & $\begin{array}{l}\text { I was clear about the objectives of the } \\
\text { multimedia learning module }\end{array}$ & 3.33 & .761 & 41.7 \\
\hline 28 & $\begin{array}{l}\text { I knew better about the subject with the } \\
\text { multimedia learning module }\end{array}$ & 3.33 & .761 & 41.7 \\
\hline
\end{tabular}

This learning environment was considered to be the scaffolding level, where there was face-to-face teaching but with lesser teaching or explanation given and multimedia learning module was used to replace the PowerPoint slides. When students started to be involved in the learning process, they would be well aware of the topics which they were learning and they could understand the information presented in the multimedia module, it would assist students successfully achieved the learning outcomes (see Table VII). The grand mean score for this learning environment was very 
close with the conventional teaching environment, which were 3.53 .

TABLE VIII: UNDERSTANDING (WEB)

\begin{tabular}{|l|l|l|l|l|}
\hline No & Survey Items & $\begin{array}{l}\text { Mean } \\
(\mathbf{M})\end{array}$ & STD & $\%$ \\
\hline 2 & I understood the content easily. & 4.07 & .767 & 82.9 \\
\hline 5 & $\begin{array}{l}\text { I could understand the instructions in the } \\
\text { web-based multimedia learning module. }\end{array}$ & 4.03 & .589 & 87.1 \\
\hline 14 & $\begin{array}{l}\text { The information in the module was based on } \\
\text { the syllabus. }\end{array}$ & 3.96 & .711 & 78.6 \\
\hline 17 & $\begin{array}{l}\text { I could achieve all the objectives for this } \\
\text { chapter. }\end{array}$ & 3.96 & .788 & 77.1 \\
\hline 18 & $\begin{array}{l}\text { I understood better through the use of } \\
\text { multimedia. }\end{array}$ & 3.94 & .866 & 72.9 \\
\hline 21 & $\begin{array}{l}\text { Multimedia content helped me to learn } \\
\text { better. }\end{array}$ & 3.91 & .913 & 67.1 \\
\hline 23 & $\begin{array}{l}\text { Web-based module helped me understood } \\
\text { the chapter. }\end{array}$ & 3.89 & .733 & 72.9 \\
\hline 31 & $\begin{array}{l}\text { After this web-based learning, I gained much } \\
\text { knowledge. }\end{array}$ & 3.77 & .820 & 67.1 \\
\hline 32 & The objectives were made clearly to me. & 3.77 & .820 & 67.1 \\
\hline
\end{tabular}

From Table VIII above, it presents the survey items related to learner understanding. In this study, the web learning environment was shown that it improved learner understanding. The grand mean score achieved for this factor is 3.92 , which is very close to 4.00 . This web learning environment had successfully transferred the knowledge to students and students showed high preference towards such learning environment.

\section{Motivation}

TABLE IX: MotIVATION (F2F)

\begin{tabular}{|l|l|l|l|l|}
\hline No & \multicolumn{1}{|c|}{ Survey Items } & $\begin{array}{c}\text { Mean } \\
\text { M) }\end{array}$ & STD & $\%$ \\
\hline 15 & $\begin{array}{l}\text { I enjoyed learning with the conventional } \\
\text { method of teaching }\end{array}$ & 3.50 & .855 & 42.9 \\
\hline 17 & I found the lecture interesting and engaging & 3.43 & .852 & 50.0 \\
\hline 18 & I liked the conventional method of teaching. & 3.29 & .914 & 42.8 \\
\hline 19 & $\begin{array}{l}\text { I was interested to learn more about the topic } \\
\text { after the lecture }\end{array}$ & 3.14 & .663 & 28.6 \\
\hline 20 & $\begin{array}{l}\text { I was motivated learning with the } \\
\text { conventional method of teaching }\end{array}$ & 3.07 & 1.072 & 28.6 \\
\hline
\end{tabular}

Table IX presents five survey items which were related to learner motivation. Students were motivated to learn in this face-to-face teaching environment but it was found to have lower motivation as compared to the other two learning environments. The grand mean score was 3.29.

When students have the chance to interact with the multimedia module, it increases their interest in learning. Students will be able to remember longer when they are engaged with the multimedia module because they have the experience in navigating through the module. The interactivity features provided in the multimedia module would help to make the learning to be more fun (see Table X). The grand mean score for this learning environment was higher than the conventional teaching environment, which were 3.59 .
TABLE X: MOTIVATION (MM)

\begin{tabular}{|l|l|l|l|l|}
\hline No & Survey Items & $\begin{array}{l}\text { Mean } \\
(\mathbf{M})\end{array}$ & STD & $\%$ \\
\hline 5 & I liked the multimedia learning module & 3.79 & .779 & 66.7 \\
\hline 7 & $\begin{array}{l}\text { I enjoyed learning with the multimedia } \\
\text { learning module }\end{array}$ & 3.79 & .833 & 70.9 \\
\hline 8 & $\begin{array}{l}\text { I liked learning with this method than in the } \\
\text { traditional classroom }\end{array}$ & 3.75 & .676 & 62.5 \\
\hline 11 & Multimedia made learning fun and motivating & 3.75 & .676 & 70.8 \\
\hline 15 & $\begin{array}{l}\text { I liked being able to learn with } \\
\text { multimedia-oriented modules }\end{array}$ & 3.54 & .588 & 58.3 \\
\hline 18 & I liked the multimedia content in the module & 3.50 & .659 & 50.0 \\
\hline 19 & I was motivated learning with the module & 3.50 & .590 & 54.2 \\
\hline 20 & $\begin{array}{l}\text { I found learning with the module interesting } \\
\text { and engaging }\end{array}$ & 3.50 & .834 & 54.1 \\
\hline 21 & $\begin{array}{l}\text { I was interested to learn more about the topic } \\
\text { after going through the multimedia learning } \\
\text { module }\end{array}$ & 3.50 & .722 & 54.2 \\
\hline 22 & $\begin{array}{l}\text { The interactive features in the module made } \\
\text { learning fun and engaging }\end{array}$ & 3.46 & .721 & 50.0 \\
\hline 23 & $\begin{array}{l}\text { The interactive features in the module } \\
\text { motivated me to learn the content }\end{array}$ & 3.46 & .721 & 41.6 \\
\hline
\end{tabular}

TABLE XI: MOTIVATION (WEB)

\begin{tabular}{|l|l|l|l|l|}
\hline No & Survey Items & $\begin{array}{l}\text { Mean } \\
(\mathbf{M})\end{array}$ & STD & $\%$ \\
\hline 7 & $\begin{array}{l}\text { I find learning with the web interesting and } \\
\text { engaging }\end{array}$ & 4.00 & .643 & 86.7 \\
\hline 8 & I enjoyed learning in the web environment & 4.10 & .548 & 90.0 \\
\hline 13 & Multimedia made learning fun and motivating & 3.97 & .669 & 83.3 \\
\hline 16 & $\begin{array}{l}\text { I liked being able to learn at my own pace and } \\
\text { time }\end{array}$ & 3.90 & .885 & 70.0 \\
\hline 18 & $\begin{array}{l}\text { The interactive features in the module made } \\
\text { learning was fun and engaging }\end{array}$ & 3.87 & .730 & 73.3 \\
\hline 22 & $\begin{array}{l}\text { I liked the multimedia content in the web } \\
\text { module }\end{array}$ & 3.83 & .874 & 73.3 \\
\hline 23 & I was motivated learning on the web & 3.80 & .805 & 80.0 \\
\hline 25 & $\begin{array}{l}\text { I was interested to learn more about the topics } \\
\text { in the web module }\end{array}$ & 3.77 & .898 & 73.3 \\
\hline 27 & $\begin{array}{l}\text { I prefer this teaching / learning method in my } \\
\text { learning process }\end{array}$ & 3.77 & .774 & 70.0 \\
\hline 29 & $\begin{array}{l}\text { Interacting with the module motivated me to } \\
\text { learn the content }\end{array}$ & 3.73 & .740 & 63.3 \\
\hline 34 & $\begin{array}{l}\text { I liked learning on with this application rather } \\
\text { than the traditional classroom }\end{array}$ & 3.63 & .928 & 60.0 \\
\hline
\end{tabular}

There were eleven survey items related to learner motivation in this web learning environment as presented in Table XI. In this learning environment, students were put into an independent learning environment where they were asked to have their lesson through the access to the web-based multimedia module. The results indicated positive acceptance from the students on this learning environment and they agreed that they were motivated in learning. The grand mean score for learner motivation in this web learning environment was the highest among all, which were 3.85 .

\section{E. Students' Comments}

Students were also asked to give their comments regarding the learning environment that they had gone through. The comments were able to support the survey results and indicate their perceptions on the learning environments. Please refer to the tables below: 
TABLE XII: STUDENTS' COMMENTS (F2F)

\begin{tabular}{|l|l|}
\hline No & Comments \\
\hline 1 & "Can made me more understand the lecturer." \\
\hline 2 & $\begin{array}{l}\text { "The conventional method, is good because it help to } \\
\text { understand." }\end{array}$ \\
\hline 3 & "Some lecturer is teaching so student can absorb the knowledge." \\
\hline 4 & "More clearly and understand about the subject." \\
\hline 5 & "Gain more knowledge about the particular subject." \\
\hline 6 & "Difficult to follow." \\
\hline 7 & $\begin{array}{l}\text { "Sometimes will feel boring if lecturer present by a boring way." } \\
\text { Some lecturer might teaching too fast, the students might find } \\
\text { hard to absord the knowledge. Students might not concentrated } \\
\text { during the class." }\end{array}$ \\
\hline 10 & $\begin{array}{l}\text { "Lecturer was teaching too fast and cauldn't catch up. } \\
\text { Lecturer was not really clearly explain futher more } \\
\text { explaination." }\end{array}$ \\
\hline $\begin{array}{l}\text { "Sometimes it make me bored and tired, besides this, it is actually } \\
\text { no problem at all." }\end{array}$
\end{tabular}

\begin{tabular}{|c|c|}
\hline No & $\begin{array}{l}\text { TABLE XIII: STUDENTS' COMMENTS (MM) } \\
\text { Comments }\end{array}$ \\
\hline 1 & $\begin{array}{l}\text { "What I like about the interactive multimedia learning module is, } \\
\text { it is easy to understand." }\end{array}$ \\
\hline 2 & "Easy to understand." \\
\hline 3 & "The fully-explaination of informations." \\
\hline 4 & "I still can remember what I see in the module." \\
\hline 5 & $\begin{array}{l}\text { "Understanding the module easy bcos got pictures and } \\
\text { animation." }\end{array}$ \\
\hline 6 & $\begin{array}{l}\text { "No problem for me, understanding the module easy bcos got } \\
\text { pictures and animation." }\end{array}$ \\
\hline 7 & $\begin{array}{l}\text { "The interactive multimedia learning module was helping me by } \\
\text { showing the examples such as the devices, video, and sound." }\end{array}$ \\
\hline 8 & "It is fun and interesting." \\
\hline 9 & $\begin{array}{l}\text { "What I like about the interactive multimedia learning module is, } \\
\text { the module have all the pictures and videos to make the student } \\
\text { more understand about the topic." }\end{array}$ \\
\hline 10 & "Make learning fun and motivating." \\
\hline
\end{tabular}

TABLE XIV: STUDENTS' COMMENTS (WEB)

\begin{tabular}{|l|l|}
\hline No & Comments \\
\hline 1 & $\begin{array}{l}\text { "All the colourful pictures are provided, sound effect makes less } \\
\text { boring." }\end{array}$ \\
\hline 2 & "It was visually and interesting when learning." \\
\hline 3 & $\begin{array}{l}\text { "The using of web module helped in the learning in this course is } \\
\text { that it can easily be concentrate." }\end{array}$ \\
\hline 4 & "I am happy that I can learn on my own." \\
\hline 5 & "I don't have to worry if I am slow in learning." \\
\hline 6 & "Can learn in our own place at any time." \\
\hline 7 & "I understand the topic much more better." \\
\hline 8 & $\begin{array}{l}\text { "Can learn with fun and peace mind. So, I can understand very } \\
\text { well." }\end{array}$ \\
\hline 9 & "Make me more understand." \\
\hline 10 & "Can more understanding since I can focus more." \\
\hline
\end{tabular}

From the students' comments, it is noted that students accepted the learning environments which they went through. They found they could understand the lesson and they were motivated in the learning process. However, as a comparison, it was noted students who went through the web learning environment or learner-centred teaching achieved better understanding. They had indicated through the survey and comments where the web learning environment was motivating and they enjoyed it.

\section{CONCLUSION}

The results in this study had shown that the teaching and learning environment would affect learner understanding and learner motivation. From the Pre-test/ Post-test scores, it is noted students performed better in the web learning environment. Students accepted the use of multimedia learning module in the multimedia learning environment and also in the web learning environment. The interactivity provided in the multimedia learning module helped students to achieve better understanding and motivation. The independent learning in the web environment also encouraged students to have self-paced learning which allowed them to focus better because they could plan their own learning process. More research could be conducted on higher level students like degree or master students. It is also possible to investigate the effect of learner-centred teaching on different programme of students.

\section{REFERENCES}

[1] B. Moeller and T. Reitzes, Integrating Technology with Student-Centered Learning, Education Development Center, Inc. (EDC), Quincy, MA: Nellie Mae Education Foundation, 2011.

[2] K. Debevec et al., "Learning strategies and performance in a technology integrated classroom," Journal of Research on Technology in Education, vol. 38, no. 3, pp. 293-307, 2006.

[3] P. Shank. (2005). The Value of Multimedia in Learning, Adobe Systems Incorporated. [Online]. Available: http://www.adobe.com/designcenter/thinktank/valuemedia/The_Valu e_of_Multimedia.pdf

[4] K. Kiili, "Participatory multimedia learning: Engaging learners," Australasian Journal of Educational Technology, vol. 21, pp. 303-322, 2005.

[5] S. Oncu and H. Cakir, "Research in online learning environments: Priorities and methodologies," Computers \& Education, vol. 57, pp. 1098-1108, 2011.

[6] L. Y. Low, L. T. Low, and V. C. Koo, "Multimedia learning systems: a future interactive educational tool," Internet and Higher Education, vol. 6, pp. 25-40, 2003.

[7] T. P. Mackey and J. Ho, "Exploring the relationships between Web usability and students' perceived learning in Web-based multimedia (WBMM) tutorials," Computers and Education, vol. 50, pp. 386-409, 2008.

[8] V. Demirer and I. Sahin, "Development, implementation and evaluation of an online multimedia learning environment for blended learning," AWERProcedia Information Technology \& Computer Science, vol. 1, pp. 980-985, 2012.

[9] M. Weimer, Learner-Centered Teaching: Five Key Changes to Practice, San Francisco, CA: Jossey-Bass, 2002.

[10] J. P. McCarthy and L. Anderson, "Active learning techniques versus traditional teaching styles: Two experiments from history and political science," Innovative Higher Education, vol. 24, no. 4, pp. 279-294, 2000.

[11] D. Laurillard, "Keynote: Designing the pedagogies for student guidance on the larger scale," presented at $63^{\text {rd }}$ Annual Conference International Council for Educational Media 2013, Singapore, Oct. 1-4, 2013.

[12] L. Anglin and K. Anglin, "Business education, teaching, and the millennials," in Proc. the Academy of Business Disciplines, 2008.

[13] C. K. Chiang, H. Chapman, and R. Elder, "Changing to learner-centred education: Challenges experienced by nurse educators in Taiwan," Nurse Education Today, vol. 30, pp. 816-20, 2010.

[14] S. Devinder and A. B. Zaitun, "Mobile learning in wireless classrooms," Malaysian Online Journal of Instructional Technology (MOJIT), vol. 3, no. 2, pp. 26-42, 2006.

[15] F. D. Salajan, S. Perschbacher, M. Cash, R. Talwar, W. El-Badrawy, and G. J. Mount, "Learning with web-based interactive objects: An investigation into student perceptions of effectivess," Computers \& Education, vol. 53, pp. 632-643, 2009.

[16] D. R. McIntyre and F. G. Wolff, "An experiment with WWW interactive learning in university education," Computers \& Education, vol. 31, pp. 255-264, 1998.

[17] A. R. Jr. Smith, C. Cavanaugh, and W. A. Moore, "Instructional multimedia: An investigation of student and instructor attitudes and student study behaviour," BMC Medical Education, vol. 11, p. 38, 2011.

[18] M. Liu, P. Toprac, and T. T. Yuen, "What factors make a multimedia learning environment engaging: A case study," IGI Global, 2009. 
[19] A. Field, Discovering Statistics Using SPSS, $3^{\text {rd }}$ ed., Sage Publications, 2009.

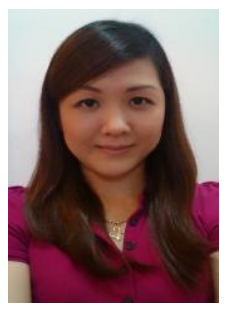

Yap Wei Li was born in Seremban, Negeri Sembilan, Malaysia on $6^{\text {th }}$ December. She received her PhD in creative multimedia, Multimedia University, Malaysia, 2014; master in computer science, Universiti Putra Malaysia, 2003; BSc (Hons.) in computer science, INTI International University, Malaysia, 2000.

She is a senior lecturer in Faculty of Science, Technology, Engineering and Mathematics, INTI International University, Malaysia. She held the position of the head of programme from 2003 to 2010. She had published in local and international conferences proceedings before, recently in a Scopus indexed journal: Impact of Learner-Centred Teaching Environment with the Use of Multimedia-mediated Learning Modules in Improving Learning Experience. Jurnal Teknologi (Sciences \& Engineering) 68:2 (2014), pp. 65-71. Her research interest is on educational technology, multimedia learning, learner-centered teaching and e-learning. Dr. Yap holds the membership in Technological Association Malaysia. She received the Best Paper Award in International Conference on Informatics and Creative Multimedia, 2013. 